\title{
A Review of Valuation Impact on Property Tax
}

\author{
Atilola Moses Idowu a , Norhaya Kamarudina, Kamalahasan Achua ${ }^{a}$, Ibisola Abayomi Solomon ${ }^{b}$ \\ ${ }^{a}$ Department of Real Estate, University Teknologi Malaysia, 81310 UTM Johor Bahru, Johor, Malaysia \\ ${ }^{b}$ Department of Estate Management Covenant University, Otta, Ogun State Nigeria \\ *Corresponding author: kamalahasan@utm.my
}

\begin{abstract}
Property taxation is universal, it is hard to find a country which does not levy a tax on its landed property. The best tax policy in the world is worth little if it cannot be implemented effectively. The level of tax yield of property has been below the expected tax yield due to assessment issue. The function of valuation is to ensure fair assessment of property owners. This paper examines the taxonomy of property tax with a view to understanding it composition and review the impact of valuation accuracy on property tax from existing literature. The study reveals the impact of valuation on property tax, indicating the effects of valuation accuracy on the amount of tax payable or receivable as the case may be. Valuation impact can be viewed as being accurate or inaccurate. When it is accurate the cost is low for the tax administration, low rate of avoidance and evasion, and provision and maintenance of municipal services, but the reverse is the case when it is inaccurate. The study recommends that tax authorities should engage qualified professionals in the assessment of property tax and that regulatory bodies should organise periodic training for their members
\end{abstract}

Key words: Equity, impact, property tax, tax yield, valuation accuracy and inaccuracy

(C) 2016 Penerbit UTM Press. All rights reserved

\subsection{INTRODUCTION}

In order to carry out a good assessment of property tax, government must put in place an effective tax system where tax payments are made by every citizen and where the canons of taxation are upheld. These canons of taxation include convenience, certainty, economy and equity in tax administration [1]. Property taxes provide a steady and reliable source of government revenue to finance public expenditures and services, especially for a local or sub-regional government $[2 ; 3 ; 4 ; 5 ; 6]$.

It has been revealed that the level of yield of property tax has been below the expected revenue yield of many authorities [7; $8 ; 9]$. Connolly and Bell [10] have described the situation in developing countries as a fiscal paradox, because a lot has been said about the potential of property tax to local authorities but much has not been achieved partly due to the issues in determining the assessment value of individual property that have impacted the revenue collection among other issues. The primary and formal function of valuation is to ensure fair assessment such that property owners with similar properties structures pay similar property tax bills [11; 12]. It therefore means that the aim of valuation is to ensure fair and equitable property assessment without it being arbitrary in the assessment of property.

One of the characteristics of a good valuation practice in tax administration is that assessed value must be fair to all parties in order to minimize contentions and disputes [13]. [14] posits that one of the major reasons for tax avoidance and evasion in Nigeria is the issue of reluctance towards acceptance of the assessment value, most especially when there is over-valuation against the tax payer. On the other hand, tax authorities loose revenue when there is under-valuation.

An over or under-valuation is what is referred to as valuation inaccuracy. Valuation uncertainty/inaccuracy is where the difference is much and is attributed to the inherent nature of valuation itself, and valuation error when a negligent act is involved and afterwards in the valuation process [15]. In property taxation, accuracy of valuation is measured as the 'valuation ratio', particu;arly in mass appraisal [7; 16; $11 ; 9 ; 17]$. Ross et al. [11], in particular, has described the situation as 'controversies in property assessment'. It is has been established that there exists no single and ideally point value for a given piece of landed property because all value estimates carry with them some degree of uncertainty. However, this must therefore be kept within reasonable limits of reliability in order for the valuation to be equitable [15].

The need to address controversies in property assessment, particularly in valuation cannot be over-emphasized. This is to ensure that property tax achieve the anticipated revenue yield and is seen to be equitable by all parties. The extent of valuation accuracy is influenced by the purpose for which the valuation is required. Babawale and Nubi [18], posited that the impact of valuation can be seen from the view of willingness to pay and revenue yield. This paper critically reviews the impact of valuation on property taxation, with focus on one of the canons of taxation that is, equity, which a valuation exercise ought to establish. Equity in taxation is ensuring that owners of properties pay property tax in accordance to the value of the properties.

The paper is structured into five sections: first section has discussed the introduction of the subject matter and the next discusses the taxonomy of property taxation. The third and fourth sections focuses on the causes of inaccuracy in valuation and the impact of valuation accuracy respectively. Section five discuss on the impact. The sixth section concludes the paper. 


\subsection{TAXONOMY OF PROPERTY TAXATION}

Taxonomy in property tax, is the arrangement from the origin to the conclusion stages of carrying out property valuation for taxation purpose. Valuation falls within tax administration, and its duty is to determine the tax burden to be shared by each taxable landed property [9]. Figure 1 shows the typical process involved in the determination of property tax.

The base of assessment is what is to be taxed. It could be only land, land and improvement/building/structures or improvement/building/structure alone $[19,9 ; 20 ; 21 ; 22]$. This is the physical element of the hereditament. The tax base is a policy statement that is usually contained in the tax law. After the establishment of the assessment base, the next thing is to determine the basis of taxing the base? This is the monetary aspect of the property. Authors such as $[7 ; 4 ; 20 ; 24 ; 9 ; 19 ; 23]$ identified the basis of assessment of property tax to include rental/annual value, capital value, self-assessment and area-based. This can be grouped into ad valorem (rental/annual value, capital value, and self-assessment) or non-ad valorem (area-based and self-assessment).

The valuation methods used to determine the monetary aspect of property for taxation purposes includes comparison, investment,residual, depreciated replacement, and Profit method. [25; 26; 27; 28]. These methods are used for the general valuation and annual valuation when new property is to be entred into the valuation list. The approach to property valuation can take one ora combination of discrete individual property survey; mass appraisers based on statistical techniques or statutory formula with or without the aid of Geographical Information System or property banding [9; 29; 30].

There used to be statutory provision for the reassessment of property on the valuation rolls/list, this is usually between five to ten yearly revaluations. The methods usually used for the reassessment are complete revaluation, indexation and simple rate adjustment [9]. Where property values are changing fast, the reassessment period that would be required is shorter. This reduces the risk of sudden, drastic shifts in tax burden from large increases in assessed values which could provoke protests, unending litigations and non-compliance [9; 18; 31].

The level of accuracy is determined by the skill and degree of competency displayed by the valuers in linking the four classes of the taxonomy of property tax together to achieve the aim of the assessment. Babaawale [9] argues that the combination of these classes ultimately determines the accuracy ofthe valuation. But the methods of valuation seem to be the critical one, as it is absolutely based on the ability of the valuer to appropriately identify, and use the methods correctly. The next section discusses the causes of valuation inaccuracy.

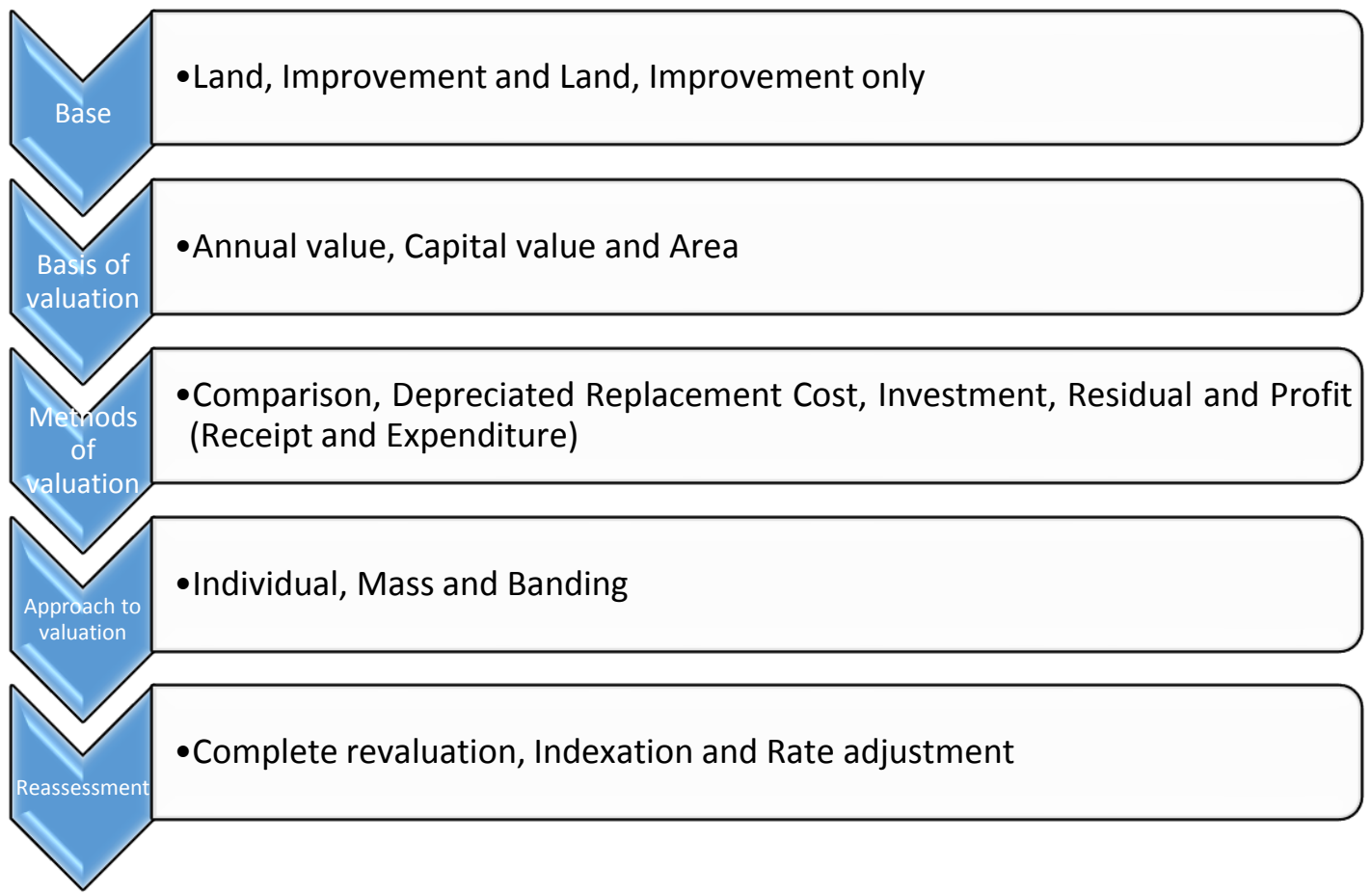

Figure 1 Taxonomy of property taxation Source: Adapted from Babawale (2013a)

\subsection{CAUSES OF VALUATION INACCURACY}

The principal factors and circumstances that have been identified in literatures as commonly contributing to disparity between valuations and subsequent transaction prices (inaccuracy), or between valuations prepared by different valuers on the same property (variance), these might be applicable to property rating valuation as well. These factors are in Valuation, [i] Individual Characteristics of Valuers and Valuation Firms. [ii] Valuation Environment, [iii] Valuation Process, and [iv] Negligence of valuer[ $33 ; 34 ; 35 ; 36 ; 37 ; 38 ; 39 ; 40 ; 41 ; 42 ; 43 ; 44 ; 45$; 46; 47]. This factors are discussed in detailed below.

\section{Individual Characteristics of Valuer and Valuation Firm}

Valuation firm can be grouped into ethical and unethical firms. The ethical firms are those not prepared to report valuation outside the range of defensible value while, the unethical firms are the opposite $[48 ; 35]$. The outcomes of valuation is determined by the structure and the 
practice standards of the firm the valuer works for, these are valuers' resume that invariably impinge on his ability to apply established valuation principles, methodology and process efficiently to achieve accurate valuation [43]. Aluko [35] argues that the level of training (academic and/or professional) of the valuer influence his or her ability to estimate the market appropriately. Other authors that have identified this factor as a source of inaccuracy in valuation include $[39 ; 40 ; 49 ; 50 ; 51 ; 52 ; 53 ; 45 ; 32 ; 47]$.

The Valuation Environment

The valuation environment is described by [48] as the external characteristics. These are elements on the external environment within which valuers operate that have been identified as having varying degrees of influence on valuation discrepancy [36; 54; 43; 45]. It represents the totality of the legal, institutional, economic and regulatory frameworks within which valuer's carries out his/ her duties. Given the nature of the task environment, valuers are made to compare, contrast, weigh and rationalize myriads of information; some of which may be conflicting. All these, directly or indirectly, affect the valuation construction process, and ultimately the accuracy of the valuation [43]

\section{The Valuation Process}

This includes the choices and factors that have to be made by valuers starting from clients' instructions to reporting the final valuation. At any stage of the process, bias may be introduced into the final valuation [55]. The variables include internal problem of the valuation methods, behavioural attitude of the valuer and quality control measures of the firm, among others. Authors such as 36, 42, 43, 44, 32 and 46 have identified this factor as one of the major causes of inaccuracy in valuation.

\section{Valuer's Negligence in Valuation}

These are ethical and attitudinal issues of valuer in discharging his or her professional duty towards his client as laid down by the regulatory body. This is actionable under the law of contract and torts $[33 ; 56 ; 43 ; 57 ; 32 ; 58 ; 59]$. Valuer's negligence in valuation cover issues like intentional fraudulent act of the valuer and carelessness attitude. The studies of 56, 60, 15, 58, 42 and 45 have identified the negligent act of the valuers as a prominent cause of inaccuracy of valuation.Having identified the causes of inaccuracy in valuation, the next section focused on the impact of valuation accuracy on property tax.

\subsection{IMPACT OF VALUATION ACCURACY ON PROPERTY TAXATION}

Property taxation is an annual charge on ownership or occupation of property, the proceeds of which is traditionally used to offset the costs of providing municipal services such as refuse disposal, provision and running of markets, maternity homes, and parks [9]. To maximise fairness and understanding in a property tax system, valuation should be based on the current market value of landed property. This is because market value tax base maintains a uniform relationship between property values and property taxes [20;4].

Valuation of property is one of the major problems affecting the effective use of the property tax [31]. The problem with valuation is either it is over-valued or under-valued. This usually affects the fairness and equality of property tax [61]. An incidence of under-valuation often reduces government's tax yield, while over-valuation results into disputes that may delay payment of property taxes [13].

The impacts of inaccuracy valuation include damage to the reputation of the valuation profession, collapse of the financial market and loss of investor confidence in the operation of property market [62; 9]. Also, Ayedun [41] argues that the impact of valuation of being inaccurate to sustainability of the mortgage market. Atilola [63] posits that impact can be looked at from three perspectives, the environment (physical), economic (revenue gained or lost) and social (unrest or protest, and unemployment). The impact of valuation accuracy peculiar to property taxation is discussed with the aid of Figure 2.

Figure 2 shows two things that will happen after the assessment or valuation of property is done, that is, accurate valuation and inaccurate valuation.

When the valuation is accurate, the likely impact is that the expected tax revenue (yield) is attained within the shortest period with lower administration cost, because the taxpayer will be willing to pay. As illustrated in Figure 3, it will therefore cost less to receive and pay the property taxes since both the tax payers and the collecting authority will not need to spend further expenses in attending to objections and appeals. Summarily, the impacts of accurate valuation on property taxation are: lower cost of administration; payment of tax within the shortest period is guaranteed and the purpose of imposing the tax will be achieved (that is, provision and maintenance of municipal services).

On the other hand, if the valuation is inaccurate, the uninformed taxpayer may still proceed to make payments, but this category of people are not many and this will eventually not increase the revenue, as most people do not generally want to pay taxes. Sheffrin [64] argues that the taxpaying public hates property taxes. However, to the informed taxpayer, he or she might go by the way of either 'self-help' (tax avoidance or evasion) or follow the judiciary procedure of assessment objection or appeal. Furthermore, when the set of people that have chosen to avoid or evade tax are able to gather themselves and form an association they often go ahead to protest against the government. In some instances, some of their actions often lead to unrest or riots [65; 66]. In the United State of America the population of tax protesters have being on the increase, study shows that in 1979, 1980 and 2001 their population are 7,139, 18,226 and 152,000 respectively [66]. This therefore suggested that as the year is going by the revenue will be reducing as shown in Figure 4.

When the taxpayer adopts the 'self-help' approach, it shows that the action disconnect from the flow-chart rule as that stage ought not to be the final stage, it stand alone. The implication of this is that, tax will not be paid at all, and tax authority will have to spend heavily on enforcement which might not succeed, because of the fundamental faulty issue. If, on the other hand, taxpayer chooses the option of judiciary procedure of appeal, it will take some time before the case is determined and resolved. Not only that, some costs such as payments to professionals that will give expert opinion and the solicitor's fees, among others, will be required to pursue this cause as the onus lies on the taxpayer to prove that the assessment is not fair. Also the tax authority will incur some costs as well. The scenario of valuation inaccuracy is illustrated in Figure 4. 


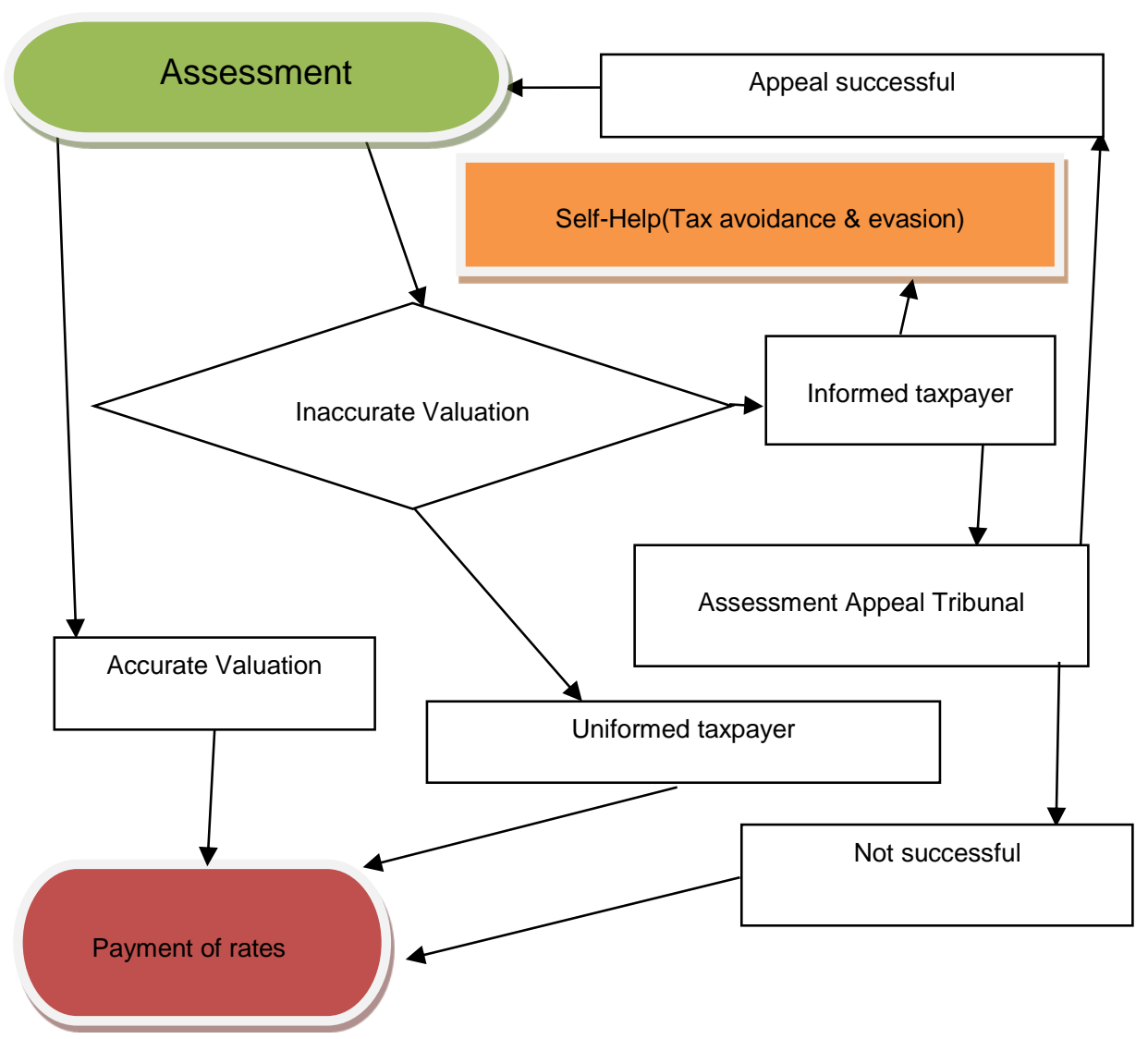

Figure 2 Impact of valuation on property tax Source: Authors work (2015)

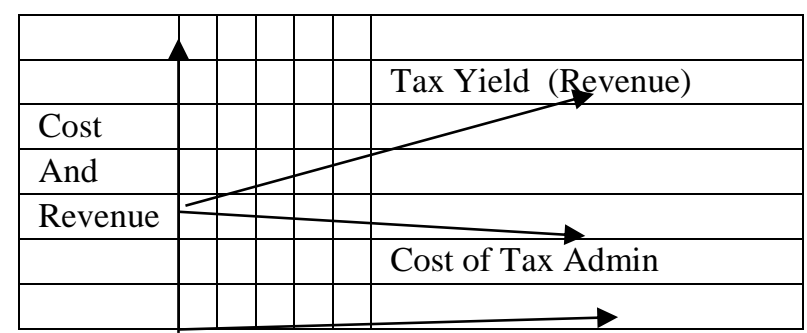

Years

Figure 3 Cost and reveune of accurate valuation Source: Authors work (2015)

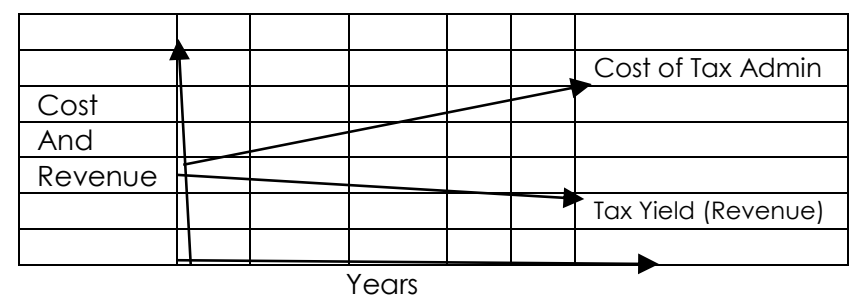

Figure 4 Cost and revenue of inaccurate valuation Source: Authors work (2015) 
Figure 4 shows that the cost is more than the revenue generated due to the issues explained above. However, the likely direct impact of valuation inaccuracy on property taxation can be summarised as follow:

There will be high cost of administration, which makes the system to be ineffective $[31 ; 2]$. Cords [66] argues that "as the number of tax protesters increases, the cost associated with collecting their taxes and prosecuting their tax avoidance also increases". A lot of fundswill be required for the objection/appeal and because some tax payers had considered the tax as being unfair or lacking equity, they often decide not to pay. To enforce compliance, additional funds will be needed for this. Hence, this makes the tax not to be certain and economically viable; leading to tax avoidance and evasion. Babawale [9], Moore [67] and Bahl [8] posit that inappropriate taxation valuation will lead to low tax yield. Also, some payment will be delayed till after the determination of the appeal [13]. Whereas, Ishaya et al [68] submitted that the error in the valuation forms a basis for proposal or objection and non-payment or non-collection of rates.

The purpose of imposing the tax will be defeated when the cost of administering is more than the revenue generated, which makes provision of municipal services as well as the maintenance of the existing infrastructure difficult [18; 10; 7]. Alias [69] posits that when the tax authority could not collect rates it may lead to negative form of financial control, a situation where a local authority is forced to reduce its budgetary allocation for some goods and services due to shortage of revenue. This art of 'negative form of financial control' often cause what Akindele [70] called 'secondary abandonment', a situation where government refused to provide infrastructure in neighbourhoods suffering from abandonment arising from low tax yield.

The indirect impacts of inaccurate property valuation that can be deduced are: Unemployment- as the agency that ought to recruit people to provide and maintain services will not have the financial strength to do so. This often leads to other social problems in the community.Inaccuracy in property tax valuation also causes unrests or riots which constitute social, political and economic challenges.

\subsection{DISCUSSION}

The method of valuation was identified as a major determinant of accuracy of valuation in the tax taxonomy. The methods are been influenced by individual characteristics of valuer and valuation firm; valuation environment, valuation process and negligence act. It reveals from the study that the impacts of valuation on property tax include economic (tax avoidance and evasion), environmental (secondary abandonment poor infrastructure), and social (unemployment and protest)

The best tax policy in the world is worth little if it cannot be implemented effectively. How a tax system is administered affects it yield, its incidence, and its efficiency. An administration that is unfair and capricious may bring the tax system to being disreputableand weaken the legitimacy of state actions [71]. When equity (fairness) is missing in the canons of taxation, convenience, certainty and economy will be absent in property tax administration.

\subsection{CONCLUSION}

The consequences of valuation not being accurate in property taxation are on compliance (willingness to pay) and revenue yields. It will amounted to tax revolts and protests which frequently subsume large economic, political, social and even religious issues, with the identified impacts of accuracy of property tax valuation on the tax authority, tax payer and general public on one side, and for local government/suburban area to be able to maintain their autonomy, their capacity to generate the revenue that will sustain them is paramount mostly from property taxation. This study therefore suggests the engagement of seasoned Valuers to undertake the property assessment. Also, regulatory bodies should provide periodic training for it members so as to make them fit for the job.

\section{References}

Adair, A., Hutchison, N., MacGregor, B., McGreal, S., \& Nanthakumaran, N. (1996). An analysis of valuation variation in the UK commercial property market: Hager and Lord revisited. Journal of Property Valuation and Investment, 14(5), 34-47.

Adegoke, O.J. and Aluko B.T. (2007). Heuristic Behaviour in Valuation Practice in Lagos Metropolis. The Estate Surveyors and Valuers, 30 (1), 5-12.

Akinjare O.M., Iroham O.C., and Oloke. O.C. (2013). Valuation Discrepancies in the Value of Professional Valuers in Lagos, Nigeria. International Journal of a Economy, Management and Social Sciences, 2(6), $272-276$.

Akindele, O. A. (2011). Landed Property Abandonment: A Factor of Inter-City Disparity in Ogbomoso and Osogbo, Nigeria: In Afon, A.O. and Aina, O.O. (Eds): Issues in Built Environment of Nigeria; pp 170 -185, Ile-Ife, Nigeria, OAU Press.

Alias, B.(2002). Analysis of The Factors That Contributed To The Accumulated Of Uncollected Rates in Local Authorities in Malaysia. Unpublished Ph D. Thesis, Universiti Teknologi Malaysia.

Aluko, B.T. (2000). A Study of Appropriateness of Mortgage Valuation for Institutional Lending in Nigeria. Doctor Philosophy, Obafemi Awolowo University, Ile-Ife. Aluko B.T (2005), Building Urban Local Government Fiscal Autonomy through Property Taxation Financing Option. International Journal of Strategic Property Management 9: 201- 214.

Amidu, A.-R., and Aluko, B. T. (2007a). Client Influence in Residential Property Valuations: an Empirical Study. Property Management, $25(5), 447-461$.

Amidu, A. R., and Aluko, B. T. (2007b). Client Influence on Valuation: Perceptual Analysis of the Driving Factors. International Journal of Strategic Property a Management, 11(2), $77-88$.

Amidu, A., Aluko, B.T., and Hansz, A. J. (2008). Client Feedback Pressure and the Role of Estate Surveyors and Valuers. Journal of Property Research, 25(2), 89-106. Ajibola, M. O. (2010). Valuation Inaccuracy: An Examination of Causes in Lagos Metropolis. Journal of Sustainable Development, 3(4), 187-193.

Atilola, M.I. (2008). An Examination of Environmental Impact of Vacant and Abandoned Properties in Lagos. Master of Science, University of Lagos, Akoka-Yaba.

Atilola M.I. (2013), Reconciling the provisions of the Land Use Act and The Kwara State Land Charge Law. WABER Conference Proceeding, held at British Council, Accra, Ghana between 12th and 14th August, 961- 973.

Ayedun, C. A. (2009). Reliability and Consistency of the Investment Method of Valuation: A Study of Lagos Metropolis. Master of Science Covenant University, Otta.

Ayedun C.A., S.A. Oloyede, A.S. Oni and R.A. Alimi (2015). Towards ascertain the Acceptable margin of Error to Property Investment Valuation Stakeholders in a Nigeria. European Journal of Business and Management, 7(3), 184-197.

Babawale, G.K. (2007).Valuers' Liability for Negligence. The Estate Surveyor and Valuer, 30(1), 49 - 56. 
Babawale, G. K. (2013a). Designing Appropriate Valuation Model For Sustainable Property Tax System In Developing Countries. International Journal of Law and Management, 55, 226-246.

Babawale, G.K. (2013b) Valuation Accuracy - The Myth, Expectation And Reality. African Journal of Economic and Management Studies, 4(3), 387 - 406.

Babawale, G. K. (2008). An Evaluation of Factors Influencing Inaccuracy in Residential Property Valuation in Lagos Metropolis. Doctor Philosophy, University of Lagos, Nigeria.

Babawale, G. K., \& Nubi, T. (2011). Property Tax Reform: An Evaluation of Lagos State Land Use Charge, 2001. International Journal of Law and Management, 53, $129-148$.

Babawale, G. K., and Omirin, M. (2012). An Assessment Of The Relative Impact Of Factors Influencing Inaccuracy In Valuation. International Journal of Housing Markets and Analysis, 5, 145-160.

Bahl, R. (2009). Property Tax Reform in Developing Countries. United States Agency for International Development, (07). Retrieved from http://www.amazon.com/Property-Tax-Reform-Developing-Countries/dp/0792380959.

Bahl, and Martinez-Vazquez (2006). The Property Tax in Developing Countries: Current Practice and Prospects. International Studies Program Working Paper 06-37 of Andrew Young School of Policy Studies, Georgia State University, Atlanta, United State of America.

Baum A., Crosby, N., Gallimore, P. McAllister, P., and Gray, A. (2001). The Influence of Valuers and Valuations on the Workings of the Commercial Property Investment Market: Research Funded by the Education Trusts of the Investment Property Forum, Jones Lang LaSalle and Royal Institution of Chartered Surveyors.

Bird, M.R. (2008). Tax Challenges facing Developing Countries. Inaugural Lecture of the Annual Public Lecture Series of the National Institute of Public Finance and Policy, New Delhi, March 12 .

Bond, P. H and P.K. Brown (2011). Rating Valuation Principles and Practice 3rd Edition, Oxford: Elsevier Limited.

Boyd, T. and J. Irons (2001). Valuation Uncertainty V Negligence: What is Reasonable Care? Is it being Achieved? Pacific Rim Real Estate Society Conference, held at Adelaide between January 21-24.

Boyd, T. and J. Irons (2002). Valuation Variation and Negligence: The Importance of Reasonable Care. Pacific Rim Property Journal, 8(2), 107-126.

Braybrooks, M., Charles, J., \& Zamperini, B. (2008). Taxable Property Value Exploratory Research Stusy. Proceedings of the 103rd Annual Conference of the National Tax Association.

Brown, M. (2013). Property Rates in Hong Kong: Assessment, Collection and Administration, Hong Kong SAR Government: Rating and Valuation Department.

Brownell, A. (2000). Negligence and the Valuation Industry in the Year 2000. www.prres.net.

Burg, D. F. (2004). A World History of Tax Rebellions: An Encyclopedia of Tax Rebels, Revolts and Riots from Antiquity to the Present. New York and London, Taylor and Francis Books International.

Connolly, K., \& Bell, M. (2010). Financing Urban Government In Transition Countries: Assessment Uniformity And The Property Tax. Environment and Planning C: Government and Policy, 28, 978-991.

Cords, D. (2006). Tax Protestors and Penalties: Ensuring Perceived Fairness and Mitigating System Costs. Brigham Young University Law Review, 1515 - 1571.

Crosby, N. (2000). Valuation Accuracy, Variation And Bias In The Context Of Standards And Expectations. Journal of Property Investment and Finance, $18(2), 130-161$.

Diaz, J. and Hansz, A. (2007) Understanding The Behavioural Paradigm in Property Research. Pacific Rim Property Research Journal 13(1): 16-34.

Dillinger, W. (1988). Urban Property Taxation in Developing Country. International Bank for Reconstruction and Development/The World Bank Working Papers.

Franzsen C.D.R. (2002), Property Assessment for Rating Purpose in Southern and East Africa: Present Status and Future Prospects". Paper presented at the 8th annual conference of the Pacific Rim Real Estate Society in Chris church New Zealand, between 21-23 January.

Havard, T. (2001). Valuation Reliability and Valuer Behaviour: Research Papers Funded by Royal Institution of Chartered Surveyors Foundation Research Paper Series, $4(1), 1-47$

Hefferan, M.J. and Boyd, T. (2010). Property Taxation and Mass Appraisal Valuations in Australia-Adapting to a New Environment. Property Management, 28(3), 149162.

Iroham, C.O. (2012). Heuristic in Property Investment Valuation in Nigeria. Doctor Philosophy, Covenant University, Nigeria.

Ishaya, D. A., Dabo, D., \& Makama, B. (2012). Enhanced Procedure for Property Tax Assesment and Collection in Kaduna North Local Government Area of Kaduna State - Nigeria . In Annual Worldbank Conference on Land and Poverty: The WorldBank- Washington DC, April 23 - 26 (pp. 1 - 15 ).

Kamalahasan, A, W. Lim, B. Burhaida, and F.N. Muhammad (2015). Factors Affecting Client Influence on Property Valuation in Malaysia: Do Client Size and Size of Value Adjustment Matter? Jurnal Teknologi, 75(10), $39-49$.

Kayuza, M.H. (2006), Real property taxation in Tanzania. An Investigation On Implementation And Taxpayer Perceptions|; unpublished Phd. Thesis submitted to Building and Real Estate Economics, Royal Institute of Technology, Stockholm,.

Kelly, R., \& Musunu, Z. (2000). Implementing Property Tax Reform in Tanzania Lincoln Institute of Land Policy Working Paper Lincoln Institute Product Code : WP00RK1. Lincoln Institute of Land Policy Working Paper.

Krupa, O. (2012). An analysis of Indiana Property Tax Reform: Equity and Cost Considerations. Proceedings of the 104th Annual Conference of the National Tax Association, 160-167. Sweden.

Kuye, O. (2003). Fundamentals of Real Estate Taxation, Nigeria: Olusegun Kuye and Associates.

Levy, D., and Schuck, E. (2005). The Influence of Client on Valuations: the Clients' Perspective. Journal of PropertyInvestment and Finance, 23(1), 182 - 201.

Levy, D., and Schuck, E. (1999). The Influence of Clients on Valuations. Journal of Property Investment and Finance, 17(4), 380-400.

Mangioni, V. (2014). Defining the Basis of value in Land Taxation. 20th Annual Pacific Rim Real Estate Society Conference, 19 - 22 January, Christchurch, New Zealand.

Moore, M. (2013). Obstacles to Increasing Tax Revenues in Low Income Countries. International Centre for Tax and Development Working Paper 15

Muhammad, H., Ishak, M., \& Halimoon, N. (2012). Property Rating in Ipoh-Malaysia. European Journal of Business and Management ISSN 2222-2839 4 (7)

McClusley J.W. and M.E Bell (2008) Rental value versus capital value: Alternative Bases for property tax International studies programme 08-18 Andrew Young School Of Policy Studies Georgia State University, Atlanta, G.A.

McCluskey, W. J., \& Franzsen, R. (2005). An Evaluation Of The Property Tax In Tanzania: An Untapped Fiscal Resource Or Administrative Headache? Property Management, 23, 43-69.

McCluskey, W.J., Plimmer, F.A.S and Connellan, O.P. (2002). Property Tax Banding: A Solution for Developing Countries. The Assessment Journal, 9 (2), 37 - 57.

McGreal. S. and Paz,T.D.L. (2012). An Analysis of Factors Influencing Accuracy in the Valuation of Residential Properties in Spain. Journal of Property Research, 29(1). 1-24.

Ogunba, O.A and Ojo, O. (2007) Resolving Reliability, Consistency and Rationality Problems of Professionally Prepared Valuations in Nigerian Practice, The Estate Surveyors and Valuers, 30(1), 39-48.

Ogunba, O. A., and Iroham, C.O. (2010). A Search for an Acceptable Margin of Valuation Error: A Case Study of Valuers and Their Clients in Nigeria. Sri Lankan Journal of Real Estate, 4, $54-73$.

Oluwadare, C. O., and Ojo, O. (2014). Database Creation for Tenement Rate Collection: The Role of GIS. The Pacific Journal of Science and Technology, 15(1), 190 199.

Oni O.A., and C.A Ajayi. (2011). Effects of Property Tax on Sustainable Housing Delivery in Lagos State, Nigeria. Sustainable Development, 4(1), 173-192.

Plimmer, W., J. McCluskey, and Owen Connellan (2000). Equity and Fairness within Ad Valorem Real Property Taxes Frances Lincoln Institute of Land Policy Working Paper Lincoln Institute Product Code : WP00FP1. Taxes.

Plimmer, F., and McCluskey, W. J., (2010). The Basis and Administration of the Property Tax: What can be learned from International Practice? International Federation of Surveyors Conference, 11-16 April, Sydney, Australia, 1 - 13.

Rayner, M. (1978). National and Local Taxation, London: The Macmillan Press Limited.

Ross, J. M., \& Duncan, D. (2012). Controversies in Property Assessment. Proceedings of the 105th Annual Conference of the National Tax Association, 120-123. 
Salmaso, E. (2014). Property Taxation in Theory and Practice. Unpublished Disertation, Dipartimento Di Scienze Economial E Management/ Universita' Degli Studi Di Padova.

Shapiro, E., Davies, K and Mackmin, D. (2009). Modern Methods of Valuation 10th Edition, London: Estate Gazette.

Sheffrin, M.S. (2008), "Fairness and market value property Taxation" International studies programme 08-22; Andrew young school of policy studies Georgia state university, Atlanta, G.A.

Umeh, O. L (2014).Variances in Values of Residential Property Resulting from Valuers ' Approach in Anchoring and Adjustment Heuristic in Metropolitan Lagos. Doctor Philosophy, Nnamdi Azikwe University, Nigeria.

Uviomo, Akpo (2009), The People as Government: Imperatives of Tax Payment; Being A Paper Presented at the 1st Akwa-Ibom State Revenue Summit, between 6th \& 7 th April. www.ahwaibomrevenue.com.

Young, R. E. (2014). 2013 Ratio Report. State of Mary Land, Department of Assessment and Taxation.

Wyatt, P. (2003).How Much Wrong Is Right? Variance in Commercial Property Valuation. Available at:www.ricsfoundation.org/publish/ documents.aspx?did $=2893 \& f=y$ 